Nathaniel Mitchell and Michael Haugh

\title{
Agency, accountability and evaluations of impoliteness
}

DOI $10.1515 / \mathrm{pr}-2015-0009$

Abstract: It is now well recognized that the recipients' evaluations need to be given serious consideration when theorizing impoliteness. Yet despite the importance placed on evaluations by recipients, the role of the recipient in interaction has been reduced through theorizing within the field to the ascribing of (perceived) intentions or interpreting of (perceived) social norms and expectations. We suggest, in this paper, that this under-theorizes the role of the recipient vis-à-vis evaluations of impoliteness. Building on an account of (im)politeness as social practice (Haugh 2013b, 2015; Kádár and Haugh 2013), we argue that evaluations of impoliteness inevitably involve those recipients construing the speaker's action as a particular kind of social action, and holding them accountable for that particular kind of social action with respect to particular dimension(s) of the moral order (Haugh 2013a, 2015). The accountability of social action is underpinned, in part, by the presumed agency of participants. Agency involves the socially mediated capacity to act that is afforded through 1. knowing one has the ability to act, 2. knowing that these actions may affect others (and self), and 3. knowing that one will thus be held accountable for those actions (Ahearn 2001; Duranti 2004; Mitchell forthcoming). We argue that a focus on agency in theorizing impoliteness allows for the ways in which recipients do not just simply invoke social norms or (in some cases at least) perceived speaker intentions in evaluating talk or conduct as impolite, but may also exercise their own agency in construing the speaker's actions as a particular kind of action, and thus as offensive or not. It is concluded that the agency exercised by recipients with respect to the degree to which they hold speakers accountable for impolite or offensive stances needs to be examined more carefully in theorizing about (im)politeness more generally.

Keywords: impoliteness, social action, evaluation, intention, social norm, agency, interactional pragmatics

Nathaniel Mitchell, School of Languages and Linguistics at Griffith University, Brisbane, E-mail: nathaniel.mitchell@griffithuni.edu.au

Michael Haugh, School of Languages and Linguistics at Griffith University, Brisbane, E-mail:m.haugh@griffith.edu.au 


\section{Introduction}

In the past twenty years there have been a number of important developments in the field of (im)politeness research. First, rather than solely concentrating on politeness there has been a move to treat impoliteness as an important area of research in its own right. Second, the understandings of participants themselves (so-called "first order" understandings) rather than solely the interpretations of (im)politeness theorists (so-called "second order" understandings) have been increasingly regarded as the appropriate starting point for any analysis of (im)politeness. Finally, the so-called "hearer's evaluation" and the role of (perceived) social norms has been given a place of prominence alongside the (perceived) intentions of the speaker in question. ${ }^{1}$ While many of these various developments were foreshadowed in Eelen's (2001) rather telling critique of earlier attempts to theorize politeness, they have been developed in much greater depth and scope by the numerous scholars who have championed the study of impoliteness and verbal aggression in the field over the past twenty years (e.g., Bousfield 2007, 2008; Archer 2008; Blitvich 2009; Bousfield and Locher 2008 and references therein: Culpeper 1996, 2008, 2011a; Mills 2003, 2005; Watts 2003; Locher and Bousfield 2008; Haugh 2010a).

Yet despite this broad consensus in the field, one issue that has remained somewhat unresolved amongst impoliteness researchers is the role of (perceived) speaker intentions (e.g., Culpeper 2005; Archer 2008; Bousfield 2008, 2010; Terkourafi 2008), and (perceived) social norms (e.g., Locher and Watts 2008; Culpeper 2011a), vis-à-vis evaluations of impoliteness. Bousfield (2010: 120), for instance, maintains that impoliteness is prototypically "intentionally gratuitous" and "purposefully performed", thereby placing more emphasis on hearers attributing to the speaker an intent to be impolite in giving rise to impoliteness. Culpeper (2011a: 254), in contrast, places greater emphasis on the moral grounds of impoliteness in claiming that "situated behaviours are viewed negatively - considered 'impolite' - when they conflict with how one expects them to be, how one wants them to be and/or how one thinks they ought to be". He also explicitly notes that "people [can] take offence even if they know that the behaviour that caused it was not fully intentional" (Culpeper 2011a: 69). The issues at play here might seem prima facie to be primarily definitional ones. For instance, Bousfield $(2008,2010)$ recognizes that "incidental” and "ac-

1 There are a number of very useful overviews of (im)politeness research that summarize these developments from varying perspectives, which are all well worth consulting (e.g., Culpeper 2011b; Grainger 2011; Mills 2011; Kádár and Haugh 2013). 
cidental" face-threats ${ }^{2}$ are something which a theory of impoliteness needs to accommodate, albeit preferring not to call such cases impoliteness per se.

Our view, however, is that such debates mask a critical epistemological assumption underpinning the very moral grounds of impoliteness itself, namely, the presumed agency of both speakers and recipients. The agency presumed on the part of participants in engaging in social interaction is what underpins, at least in part, the various ways in which they may be held committed to or accountable for particular social actions and meanings (Haugh 2013a, Haugh 2015). Our approach thus echoes Grainger's (2013) call to return to an account of (im)politeness that focuses on what participants are doing. However, rather than building on traditional speech act theory, in an account of (im)politeness as social practice (Haugh 2013b; Kádár and Haugh 2013), it is claimed that it is the accountability of participants for particular kinds of social actions vis-à-vis particular dimensions of the moral order (Haugh 2015) that lies at the heart of evaluations of (im)politeness.

In some respects our call for greater analytical focus on agency and accountability vis-à-vis evaluations of impoliteness is tacit in prior work, although it has not yet been explicitly theorized in those terms. ${ }^{3}$ The agency of speakers, for instance, is arguably implicit to models of impoliteness strategies (e.g., Culpeper 1996, forthcoming; Bousfield 2008). The agency of recipients is also, we would suggest, implicit to models of participant response options in the face of (perceived) impoliteness (Culpeper et al. 2003: 1563; Bousfield 2007: 2214, 2008: 219; Dobs and Blitvich 2013: 126). Within such models it is admitted that recipients may choose, for instance, to "not respond" (i.e., "stay silent") when confronted with an offence triggering event (Bousfield 2007: 2196, 2008: 188), or may enlist various "defensive counter strategies", such as to "ignore the face attack", "offer insincere agreement” or "offer an account” (Culpeper et al. 2003: 1566-1567; Bousfield 2007: 2200, 2008: 197-198).

Yet despite this tacit recognition of the import of speakers' and recipients' agency, current accounts of impoliteness largely position recipients as simply perceivers of speaker intentions and/or interpreters of presumed - albeit sometimes disputed - social norms. It is generally assumed impoliteness arises when

2 Incidental face-threats "arise as an unplanned but sometimes anticipated by-product of action - action the offender performs in spite of its offensive consequences, though not out of spite", while accidental face-threats involve "offence [that] seems to be unintended and unwitting” (Bousfield 2008: 68, 70, citing Goffman 1967: 14; although cf. Bousfield 2010: 121). 3 Brown and Levinson (1987: 68, 71) used in passing the term "rational agent". However, we note that there has been very little work undertaken in (im)politeness research to date to further develop their initial assumptions about agents or agency. 
recipients perceive an impolite intention (e.g., Bousfield 2008, 2010) or interpret some behaviour as in breach of presumed/perceived social norms (e.g., Locher and Watts 2008), or some contextually-sensitive combination of these (e.g., Culpeper 2011a). We argue that a focus on the participants' agency in theorizing impoliteness recognizes that recipients do not simply invoke social norms, or (in some cases at least) simply orient to perceived speaker intentions, in evaluating talk or conduct as impolite. Any recipient - ratified or not - is presumed to have the ability to exercise their own social-mediated agency in construing their evaluation of some prior speaker's action (including their own) as a particular kind of action, thereby licensing their evaluation of that talk or conduct as offensive, and thus impolite.

In this paper, we first briefly overview the notions of agency and accountability with respect to social action, thereby laying the conceptual groundwork for our subsequent analysis and theoretical discussion. In section three, we describe the dataset and analytical approach we draw from in substantiating our theoretical claims. Given our analytical and methodological framework is grounded in interactional pragmatics (Haugh 2007, 2015; Arundale 2010), the approach we take is, as Culpeper (2011b) points out, broadly discursive, and so reflects the epistemological and ontological commitments of other discursive approaches. We then move, in section four, to analyze in considerable detail two excerpts from recordings of face-to-face getting acquainted interactions, along with follow-up interviews with those participants. We focus in our analysis, in particular, on instances of other-criticism, and how the recipient of this implied criticism responds. What is notable is that despite those instances of other-criticism providing grounds in the context of a first encounter for an evaluation of the speaker as impolite, something that was alluded to by the recipients themselves in subsequent follow-up interviews, the recipients of those criticisms went to some lengths to be seen as not taking offence. In this way, then, we argue that the exercising of agency by those participants demonstrably comes to the fore. We conclude from this analysis that the theorization of (im)politeness needs to involve not only recourse to (perceived) intentions and social norms, but also the socially-mediated agency of participants. We are thus suggesting that the accountability of social action - and thus evaluations of impoliteness these social actions can occasion - is mediated in part through the presumed agency of those participants.

\section{Agency, accountability and social action}

The notion of agency is often invoked in accounting for social action. An individual is held committed to or accountable for an action if they are perceived 
as the one who exercised their agency in producing that action (i.e., they are agent of that action). Agency is thus a core fundamental capacity that is presumed to be available - albeit to varying degrees - to most individuals (McElhinny 1998: 181). Generally speaking, agency is defined as "the socio-culturally mediated capacity to act [or not act]" (Ahearn 2001: 112). The actions we make and the options we have available to us for acting are motivated and constrained (to some extent) by the sociocultural interactive moment we find ourselves in. Terkourafi (2011: 353), for instance, briefly notes the role of agency with respect to a speaker's ability to choose particular socially-indexical expressions. In our construal, an agent exercises their agency not only in conforming to perceived constraints governed by the sociocultural environment, but in performing any action (including resistance). However, choosing as an action is, of course, not purely governed by personal agency, but also with respect to the environment from which particular 'choices' are available. Exercising agency in making selections or resisting the action of selecting is thus invariably socially mediated (Mitchell forthcoming).

Building on prior work in sociology and anthropology (Ahearn 2001; Duranti 2004), we propose agency to encompass:

A socially-mediated awareness on the part of persons that

(i) they have some degree of control over their own behaviour,

(ii) their actions in the world affect other persons (including themselves), and

(iii) their actions are the object of evaluations (by others and themselves).

(adapted from Duranti 2004: 453)

In this view, the socially-mediated agency of participants underlies both their performance of social action, and the way in which producers can be held accountable for performing social action.

The agency of producers affords or licenses recipients to evaluate some prior talk or conduct as projecting a particular kind of social action, and attribute accountability for any valanced evaluation to the person whose agency is presumed to underlie that action. These valanced evaluations include evaluations of (im)politeness, as social action is arguably an inherently moral undertaking (Garfinkel 1967), but many others besides (Haugh and Bousfield 2012; Haugh et al. 2013: 4; Kádár and Haugh 2013: 61-64; Culpeper and Haugh 2014: 197-198). The morally-imbued nature of social action, and the ways in which it can occasion evaluations of (im)politeness, is a consequence of the way in which the recognizability of social actions is not only rooted in the seen but unnoticed expectancies of the moral order (Heritage 2012, 2013; Stevanovic and Peräkylä 2012, 2014; Haugh 2013b, 2015; Clayman and Heritage 2014), but also 
in "familiar scenes of everyday affairs" that are regarded by members as familiar scenes "because it is morally right or wrong that they are so" (Garfinkel 1967: 35). ${ }^{4}$ In other words, the ascription or construal of social action by participants is an inherently moral activity because social actions are invariably open to evaluation as good/bad, appropriate/inappropriate, polite/impolite and so on by participants (Haugh 2013b, 2015; Kádár and Haugh 2013).

Building on the observation that evaluation itself constitutes a social action (Potter 1998; Haugh 2013b), it follows that recipients can not only hold prior speakers accountable for particular kinds of social actions through evaluations, but they can also themselves be held reflexively accountable for making those evaluations a part of the interactional record. As the conversation analysis (CA) tradition has made apparent, a response on the part of a recipient to a prior action itself constitutes an action (Drew 2011), for which they subsequently may be held accountable. It is important to acknowledge that just as a producer may finely tune the production of talk or conduct for recipients (Sacks et al. 1974), so can the recipient of that prior talk or conduct finely tune their subsequent response. In other words, a recipient has the ability to exercise their socially-mediated agency in making their evaluation inferable (or not) through the design of their subsequent turn. Our contention, then, is that recipients exercise agency in responding in ways that make available an evaluation of impoliteness to the prior speaker or alternatively elect to suppress, ignore, or defer such evaluations, because the turn which makes available the inference that one is evaluating some prior turn as impolite may itself be open to evaluation as impolite.

The exercising of agency with respect to evaluations of impoliteness is, of course, socially mediated in the sense that the interactional import of licensing the inference that one has taken offence through various aspects of turn design, sequential placement or even explicit metapragmatic comments, will vary de-

4 The term "moral grounds" can be understood in least two ways following the distinction one can make between a moral order that is rooted in the first-order understandings of members who enact "seen but unnoticed" expectancies through interaction as participants (Garfinkel, 1967: 35-36), and morality as a second-order metapragmatic understanding that is, for the most part, co-constituted amongst lay observers (cf. Haugh 2012a; Kádár and Haugh 2013: 8487). The latter may well be drawn upon as a resource in interactions (e.g., the "interventions" by bystanders discussed by Kádár and Marquez-Reiter, 2015). However, in this paper, we are focusing on facets of the moral order as (conjointly) co-constituted by participants through interaction (Arundale 2010), and we do not intend to index social morals or morality in the metapragmatic sense. The intersection between these different loci of understanding (Haugh 2012a; Kádár and Haugh 2013) is clearly of interest for further research, but lies outside the scope of this paper. 
pending on the particulars of the locally situated interaction, the ongoing relationship between the participants, and the activity type in question, among other things. In the case of initial interactions between previously unacquainted interactants amongst mainstream speakers of Anglo-Englishes (e.g., American English, Australian English, British English, and so on), for instance, there is not only a preference in the CA sense (Pomerantz and Heritage 2013) for comity, that is, pursuing agreement and avoiding overt disagreement (Svennevig 1999), but taking offence in such contexts may open that interactant to the charge of taking themselves too seriously, and thus licence negative social evaluations of them (Haugh forthcoming). We are thus not advocating the view that individuals are able to evaluate something as impolite on the basis of their own judgement alone, but rather that evaluations of impoliteness involve the exercising of agency in a way that is mediated through the broader socio-interactional context and the implications for their ongoing relationships (Arundale 2006, 2010; Sifianou 2012), as well as the evaluations of their person that the taking of offence may licence.

It is important, we also acknowledge, not to limit any theorization of agency vis-à-vis (im)politeness solely to recipients and evaluations of impoliteness, given producers can also exercise agency through the use (or not) of particular impoliteness strategies or impoliteness formulae (Culpeper 2011a, 2015). However, in the remainder of this paper we limit ourselves, for reasons of space, to an analysis of instances where recipients elected to avoid a response that could have been construed as evaluating a prior turn as offensive. These responses are seen as examples of withholding such negative evaluations, despite it being putatively impolite due to the particulars of its composition and sequential placement. Our analysis of these interactions is further confirmed through an analysis of follow-up interviews with the participants concerned (Mills 2003). Notably, however, even in the interactional context of a follow up interview, which was itself a first encounter for those interactants, while participants reported being aware of the possible offensiveness of the turns in question, they nevertheless worked to construe the implicated criticism in such a way that decreased the potential for it to be seen by the interviewer as offensive to them personally.

\section{Data and method}

The two excerpts that are analyzed in this paper are taken from a larger dataset of recordings of over 53 initial interactions between Australians and Americans 
that were recorded in Brisbane from August 2012 through to July 2014. The participants were invited to take part in the recordings as a way of getting to know new people. Two volunteers were taken into a room where recording equipment was already set up. Later they were informed that they had been recorded for the purposes of a study of communication. ${ }^{5}$ The advantage of analyzing initial interactions, as Haugh (2010b: 2111) notes, is that the entire 'history' of the participant's evolving relationship is on-record for inspection by the analyst. It thus decreases the possibility that inferences will be available to participants that draw from their previous encounters with each other, a problem for the analyst that is also noted in passing by Sifianou (2012).

The interactions were analyzed within an interactional pragmatics framework (Arundale 2006, 2010, forthcoming; Haugh 2007, 2012a, 2012b, 2013b, 2015). Interactional pragmatics is an approach to analyzing pragmatic phenomena, namely, "the study, by observer-analysts, of what particular form-function relationships are taken to mean by user-participants in particular situated, sequential contexts, and how this can vary across those participants" (Culpeper and Haugh 2014: 266), which is informed by research and methods in ethnomethodological conversation analysis (Garfinkel 1967; Heritage 1984a). It focuses on the social actions and pragmatic meanings attained in interaction by participants, the interpersonal identities and relations, stances and evaluations these social actions and meanings occasion, as well as the awareness of other participants with respect to these various pragmatic phenomena. In being informed by methods and research in ethnomethodological conversation analysis, special attention is paid to the way in which participants orient to particular dimensions of the moral order in ascribing and construing social actions and meanings, thereby giving rise to particular evaluations of (im)politeness (Haugh 2013b, 2015). In particular, attention is paid to the design and sequential placement of turns, and responses to prior turns, within the broader sequential environment in which they occur (Robinson 2013; Stivers 2013). It is suggested close examination of turn design enables the analyst to tap into inferences available to those participants that are licensed by the compositional and sequential design of those turns (Drew 2013), while close examination of responses to prior turns enables the analyst to warrant his or her inferences about the inferences of that interactant, given the way in which we respond to a turn reflects, in part, how we have understood the just prior turn (Heritage 1984a; Arundale 2010). While broadly discursive in its epistemological and ontological commitments, then, our contention is that interactional pragmatics

5 See Haugh and Carbaugh (2015) for further details about the dataset in question. 
enables the analyst to make inferences about the interactionally achieved understandings of participants that are not just plausible (e.g., open to evaluation as impolite), but licensed for those participants by the particulars of the locally situated interaction (Haugh 2007). We would add the provisos, however, that licensed inferences are, of course, defeasible, just like all pragmatic inferences (Culpeper and Haugh 2014), and that the participants themselves may be interactionally achieving not only converging but also diverging understandings (Arundale 2010). ${ }^{6}$

However, given our focus is on cases where recipients exercise agency through avoiding or suppressing evaluations of offence, we have also elected to draw from consultations with the participants themselves (Mills 2003; Gagné 2010; Spencer-Oatey 2007). These took the form of follow-up interviews conducted by either the first author or a research assistant. During these semistructured interviews, the participants were asked their impressions of what happened, what they thought of the other person, and what they thought the other person thought of them. In some cases excerpts from the recordings themselves were used to prompt impressions. However, our view is not that such data gives us 'direct' access to the evaluations made by the participants at the time of interaction. Consultations with participants represent yet "another text, another conversation, only this time the interaction is with the analyst" (Mills 2003: 45). More specifically, such "reports are interactional productions shaped by the context in which they are produced rather than [being] mere representations of the participants' interests, goals, etc.” (Pomerantz 2012: 504). For these reasons participants' reports cannot be treated as offering definitive 'proof' of their interpretations or evaluations at the time of the interaction, and the interviewer should be treated as another participant in the interaction, and not simply as a neutral elicitor of comments (Potter and Hepburn 2005; Haugh 2010c). Yet as Pomerantz (2005) also argues, consultations with participants may provide some degree of confirmation for inferences made by the analyst through their examination of the interactional data, as well as allow for the withholding of certain actions or reactions by participants to be investigated (Pomerantz 2005: 102; cf. Waring et al. 2012: 279). For those reasons, we main-

6 It is also important to note that despite our focus on close interactional analysis in this paper, we do not advocate eschewing other more quantitative or experimental approaches to the analysis of impoliteness (e.g., Terkourafi 2005; Culpeper 2011a), consistent with the agenda of integrative pragmatics (Culpeper and Haugh 2014). How the latter methods might be implemented in a way that is coherent with the social constructionist epistemological and social realist ontological commitments of interactional pragmatics (cf. Kádár and Haugh 2013: 8384) is an important area for further discussion, although see Haugh and Carbaugh (2015) for a recent attempt to combine interactional and quantitative approaches. 
tain that follow-up interviews, when analyzed appropriately, offer useful metapragmatic insights that can enrich an interactional analysis.

\section{Implicated criticisms in initial interactions}

To criticize someone involves expressing disapproval or finding fault with someone or something in which the person in question has some degree of personal investment or connection. In face-to-face openings amongst (American) speakers of English a preference for criticizing mine over criticizing yours has been observed (Pillet-Shore 2015), consistent with earlier claims that other-criticism constitutes a recognizable and recurrent impoliteness strategy amongst (British) speakers of English (Bousfield 2008: 126; Culpeper 2011a: 256). According to Culpeper (2011a: 135), other-criticisms can be accomplished "on-record" through conventionalized impoliteness formulae, or (ostensibly) “off-record” through implicational impoliteness (2011a: 169, 176). Closely related to the social action of other-criticism is that of other-challenge, namely, questioning the addressed recipient's position, stance, beliefs or assumed status and the like (Bousfield 2008: 132) as somehow flawed or deserving of disapproval.

In theories of impoliteness to date it has been held that other-criticisms are "face-threatening", and for that reason may be evaluated as impolite or offensive by recipients (Bousfield 2008: 72; Culpeper 2011a: 256). In the analysis that follows it will be suggested that while both other-criticisms and other-challenges can readily be glossed as "face-threatening", such an account does not offer a full explanation of the moral grounds for these so-called "face-threats", that is, why they may be treated as an impropriety by participants in the first place. Moreover, it does not explain why other-criticisms and other-challenges appear to be closely related, yet are nevertheless recognizably distinct social actions (even in cases where they are accomplished simultaneously through a single turn). It will be proposed that it is through orienting to particular facets of the moral order that the participants in question accomplish these as particular kinds of other-criticism and other-challenge, thereby modulating the degree to which the recipient is licensed to take offence.

The first excerpt we shall examine comes from an interaction between an American, Jill, who is a postdoctoral research fellow, and Fen, a TaiwaneseAustralian, who is a guest relations officer but interested in pursuing further postgraduate studies in biological sciences. It turns out that Fen was actually born in the United States, and so is asked by Jill whether she's travelled to US 
again since she was young. The excerpt in question begins as Fen responds that while she likes travelling overseas generally, the US is of less interest to her. ${ }^{7}$

(1) AmAus26: 10:14

$351 \mathrm{~F}$ : when I went to: the States it

352 doesn't fascinate me that much. (0.3) .hh

$353 \quad(0.2)$

$354 \mathrm{~F}:$ [(and I just)

$355 \mathrm{~J}$ : [you're saying there's not it's not

356 different enough or you is know enough of it from

357 the (.) [cul-

$358 \mathrm{~F}: \quad$ [no:

359 J: from: (0.6) .hh from I dunno television? or just

$360 \mathrm{~F}$ : there's a <stereotype> ftheref (0.2) [ that ]

361 | ((smiling)) |

$362 \mathrm{~J}:$

$[\mathrm{mhm}$ ?]

$363 \quad(0.6)$

364 F: I haven't been able to get fover£?

365

| ((smiling)) |

$366 \mathrm{~J}:{ }^{\circ}{ }^{\circ} k^{\circ}{ }^{\circ}$ [what] is tha:t.

$367 \mathrm{~F}: \quad$ [ just ]

$368 \mathrm{~J}$ : sorry $>\mathrm{I}$ w- I w's-< eI'll try not to be

369 offe(h)nded?€ HAHAHA=>no but no go ahead<

370 | ((raises palms)) ।

$371 \mathrm{~F}: \quad$ o: $\mathrm{h}_{i}(0.2)$ okay yeah $>$ um well um< (.) that's

372 cause I'm not trying to €off(h)e[nd£ you he ]heheh

373 | ((shrugs and cocks head)) |

$374 \mathrm{~J}:$

[yeah I know]

$375 \mathrm{J:} \quad{ }^{\circ}$ no I know ${ }^{\circ}$

376 F: .hh I think it's u:m (1.0) that's (0.3) it's

377 it's got this: (0.2) arrogance and ignorance

378 associated with it? [and ] a lot of Europeans?

$379 \mathrm{~J}: \quad$ [mm.]

$380 \mathrm{~F}$ : don’t like (0.2) A[mer ]icans?

$381 \mathrm{~J}: \quad$ [mm?]

$382 \quad(0.2)$

7 These excerpts are presented using standard CA transcription conventions (Jefferson 2004a). 
$383 \mathrm{J:}{ }^{\circ} \mathrm{mm} .^{\circ}$

$384(0.2)$

385 F: so I try not to portray myself as American?

386 [ I ] dunno even though I was born there?

$387 \mathrm{J:}:\left[{ }^{\circ}\right.$ yeah $\left.^{\circ}\right]$

$388 \quad(1.5)$

389 F: but (0.5) I- I KNO:W I do (.) I don't know enough

390 of the country

What is notable about Fen's account (in lines 351-354) is that she implicates a (mildly) negative assessment of the US as a reason for why she hasn't really travelled in the US, despite being interested in overseas travel in general. Jill then seeks an account for Fen's negative assessment of travel to the US through an alternate disjunctive question (i.e., p or q?) (Schiffrin 1987), namely, either that the US is not different "enough" or that Fen "knows enough from television" already (lines 355-357, 359). Although these two alternatives (either inclusive or exclusive) are nevertheless favoured as candidate answers (Pomerantz 1988) given the alternate question design (Stivers 2010), the epistemic gradient is tilted further in favour of Fen, offering her a choice of accounts that is not limited to these two alternatives (Haugh 2011).

Fen, however, rejects the proposed accounts and offers another one that involves a recognizably incipient negative assessment of not only the US but of Americans as well, through invoking "a stereotype” (line 360) that she hasn't "been able to get over" (line 364). Given it has already been established in the interaction that Jill is herself an American, any negative assessment of Americans is, of course, inferably also potentially directed at Jill herself (Sacks 1972). The potential delicacy here is oriented to by Fen who attempts to convey a less critical stance projected through smile voice in "there" (i.e., the US) (Holt 2012), as well as smiling in line 361 to indicate pursuit of an affiliative stance in the midst of her disaligning response (Sert and Jacknick 2015).

Subsequently, while Jill initially seeks an elaboration of what this stereotype involves (line 366), she immediately launches a side sequence in lines 368-369 (Jefferson 1972), which is concerned with the sort of response she might expect from Fen in the subsequent turn, namely, one that may cause her to feel offended. Through the design of the first pair part of this side sequence Jill appears to be anticipating a projectably disaffiliative response from Fen, treating it as a possible interactional trouble source through an implicated premise (Sperber and Wilson 1995), namely, that Fen is going to say something 
potentially offensive. ${ }^{8}$ The orientation to possible offence is accomplished through an explicit mention of agency on Jill's part, namely, a try-claim, delivered through suppressed laughter/smile voice (Jefferson 2004b), an interpolated aspiration particle in "offe(h)nded" (Potter and Hepburn 2010), followed by post-completion laughter particles (Shaw et al. 2013). These collectively mark the try-claim by Jill itself and the incipient elaboration of the stereotype by Fen as a delicacy (Potter and Hepburn 2010; Shaw et al. 2013), as well as indicating that Jill's response is likely to be disaffiliative (Greer et al. 2005) with the incipient disaffiliative stance on Fen's part that appears to be being anticipated by Jill. The concomitant raising of her palms by Jill (in line 370), which is here interpretable as kind of "stopping" motion, offers further evidence of the interactional delicacy anticipated by Jill. The design of this turn thus not only indicates an explicit orientation to issues of impropriety or delicacy, but also represents an attempt to manage the incipient trouble such an impropriety might raise (Shaw et al. 2013).

Fen first responds in line 371 with “oh”, thereby indexing her treating Jill's claim to try to not be offended as new information (Heritage 1984b; Schegloff 2007: 118), and initially claims acceptance of Jill's stance with “okay” (Gardner 2005; Schegloff 2007: 120). However, through "okay" she also implements, at the same time, a shift-implicative move (Beach 1993), followed by a rejection of this implicated premise on Jill's part in lines 371-372 (namely, that Fen is going to say something potentially offensive), and a subsequent intention-denial claim (Haugh 2008). Notably, mirroring Jill's prior utterance, “offended" is delivered with smile voice as well as an interpolated aspiration particle in "offe(h)nded" (line 372). These mark that there is "more going on than the mere use of the word [offence] would indicate", and in that way orient to "head[ing] off incipient action" (Potter and Hepburn 2010: 1546), namely, that of Jill taking offence. The subsequent post-completion laughter particles also orient to the incipient trouble arising here (Shaw et al. 2013), representing an attempt on Fen's part to "head off problematic recipient actions, without disrupting the progressivity of talk” (Shaw et al. 2013: 91). Jill subsequently agrees with Fen's intention-denial claim in lines 374-375. However, she also implicitly challenges Fen's epistemic claim in that she claims this knowledge is also accessible to her as well, first with a more neutral "yeah I know”, followed by a no-prefaced

8 Notably, this side sequence is treated as "interruptive" of the progressivity of the sequence by Jill (Stivers and Robinson 2006) through the repair-like "sorry" (line 368) and the restoring of progressivity through "but no go ahead" (line 369), and thus is open to evaluation as impolite by Fen (Hutchby 2008). 
"I know" through which Jill disaffiliates with the complaint inferable from Fen's prior intention-denial claim (Raclaw 2013).

In spite of this explicit orientation to the potential for offence, Fen subsequently takes a strongly negative stance about Americans: she doesn't like to be seen as American herself (line 385) even though she was born there (line 386), because Americans are seen as arrogant and ignorant (lines 378-379), and Europeans don't like Americans because of that (lines 378, 380), and by implication she does not either. In taking such a stance, the stance-taker (here Fen) evaluates an object (here Americans) and implicitly positions herself as having negative affect towards the object, as well as attempting to align herself with others (here Europeans) holding the same stance (Du Bois 2007; Du Bois and Kärkkäinen 2012). Jill's degree of affiliation with this affective stance is positioned as a contingently relevant next response.

Notably, the turn-initial "I think" (line 376) that precedes this stance-taking is here indicative that an "interactionally problematic" topic is being discussed, and, moreover, that it involves the speaker "mak[ing] an assessment about a coparticipant" (Kärkkäinen 2003: 146). ${ }^{9}$ In addition, as Fen incrementally outlines her stance over a number of turns, Jill responds with the weak acknowledgement token "mm" (Gardner 1997) with falling intonation (lines 379 and 383), followed by markedly softly delivered continuer/acknowledgement token in line 387 (Zimmermann 1993). In offering only weak acknowledgement, Jill accountably withholds at that point in the sequence an affiliative response to Fen's just prior implicated criticism of Americans. That this constitutes a withholding is also evident from the long pause that follows the evident conclusion of Fen's stance-taking (line 388), which is then followed by somewhat of an epistemic backdown on Fen's part (i.e., that doesn't know everything about the US given it's a very large country) (lines 389-390).

Throughout this extract, Fen has alluded to a negative stance on the part of Europeans and thereby implicated criticism of Americans. The potential impropriety that taking this affective stance represents for Jill is oriented to by both parties through try-claims, intention-denial claims, various forms of laughter, smiling and other non-verbal means. It is clear, then, that criticizing Americans is recognized by both parties as an interactionally sensitive act, in part because of Jill's evident incumbency in the membership category being criticized (Sacks 1972). Thus, while "identifying given strategies in a piece of data doesn't mean that it is, therefore, impolite" given such "strategies are always subject to the context they are in", as Culpeper (personal communica-

9 In other words, "I think" does not indicate epistemic uncertainty or doubt per se, but rather attends to the potential impolite implications of the stance for the recipient. 
tion, cited in Dynel 2013: 165) points out, in this case there is ample interactional evidence in both the composition and sequential design of these turns that the participants are indeed orienting to an interactionally sensitive matter that constitutes a potential impropriety.

Yet while Jill earlier orients to Fen's incipient stance on Americans as potentially offensive, and initially withholds affiliation with the stance Fen subsequently implements, Jill later goes on to affiliate with the idea that many people take that kind of stance about Americans.

(2) AmAus26: 11:14

407 J: but I kno- yeah I know you're definitely not

408 alo:ne in (.) in that idea um: and (0.2) I've

409 been around enough: (0.4) people and seen enough

410 Americans whether it's in Europe or he:re that

411 are.$h \mathrm{~h}(0.2)$ the typical really Łobnoxious: $€$

$412 \mathrm{~F}$ : yeah yeah (0.2) that's the [word yeah]

$413 \mathrm{~J}$ :

[but um: ].hh

414

415 F: you're not li- you don't come [across (like that)

$416 \mathrm{~J}:$

[but uh: (0.5) but

417 like I've had a lot of co-workers when I first

418 arri:ve here

In lines 407-411, Jill proffers agreement with Fen's stance that there are indeed “[stereo]typical really obnoxious" Americans. Notably, the term "obnoxious” in line 411 is delivered with smile voice, here modulating the critical stance towards Americans that Jill herself is taking (Holt 2012). In doing so, Jill affiliates with the claim that there are people who hold such views about Americans, a view that she construes Fen as being committed to (lines 407-408). Then on the beat of a point of turn completion (Sacks et al. 1974) following the term “obnoxious", Fen expresses emphatic agreement with Jill's choice of words (line 412). Jill subsequently indicates through a trailing-off "but" (line 413) that something has been left unsaid (Haugh 2015), and thus that Fen's emphatic agreement may have been premature.

Following a noticeable one-second gap (line 414), Fen claims that Jill “doesn't come across (like that)", i.e., that she doesn't appear to be a member of the (stereo)typical “obnoxious American” category (line 415). Yet while this appears designed to reassure Jill that Fen does not think badly of her, Fen is at the same time drawing attention to what has been left unsaid until this point, namely, that Fen's criticisms of Americans may be extended to Jill herself. In 
doing so, the implicated premise that Fen could have been thinking that about Jill arises. Jill, however, disattends this casting of her person by Fen as not being like (stereo)typical Americans through a 'but'-prefaced reporting of people she has worked with (lines 416-418), thereby treating the presumption that she could be regarded in that way as an impropriety (Haugh 2015: 270-271). Yet in spite of this, Jill goes on to affiliate with Fen's stance that Americans can be insensitive and arrogant through an extended telling about her experiences travelling with own family overseas (data not shown).

Ultimately, then, Jill construes Fen's other-criticism as directed at other (stereo)typical Americans, thereby implicitly taking the position that it is not directed at her per se. In other words, Jill construes Fen's other-criticism as depersonalized referring to an exclusive category of 'typical Americans' that does not include herself. In affiliating with this affective stance she thereby not only ratifies Fen's affective stance (Sorjonen and Peräkylä 2012), namely, her implicit claim to have the right to express negative affect towards Americans, but also Fen's deontic stance (Stevanovic and Peräkylä 2014: 190), namely, her claim to have the right to pass judgement on others. In this way, then Jill construes Fen's other-criticism as directed towards a group that does not include herself, and thereby licences her not taking offence in this case. The analytical issue that remains, however, is whether Jill may nevertheless "be offended, but fail[s] to let it show" (Dynel 2013: 166).

Jill's initial comments in the follow-up interview with the research assistant, Lara, who was making the recordings prove somewhat instructive in that respect.

(3) AmAus26_follow-up(J): 0:00

$1 \mathrm{~L}$ : oka:y so: what were your general impressions. (.) .h

$2 \quad(0.3)$

$3 \mathrm{~J}: \quad$ I'm a bit \#surprised\# (.) [honestly?

$4 \mathrm{~L}$ [y- yeah?

$5 \quad($.

$6 \mathrm{~J}: \quad$ (u-) um: (0.4) like I think most (like) (.) of the

7 the conversation went fine [bu:t ] I (1.0) I was

$8 \mathrm{~L}: \quad \quad[\mathrm{mhm}]$

$9 \mathrm{~J}$ : surprised that she was born in the $\underline{\mathrm{U}} \mathrm{S}$ bu:t I think

10 is (0.2) kind of em $\uparrow$ barrassed by it?

$11 \quad($.

12 L: oh: $\uparrow$ ri:ght.

$13 \mathrm{~J}$ : or won't tell people that?

14 L: oh: oka:y? 
Jill opens the interview by construing her response to Fen as one of "surprise", namely, at the way in which Fen was "embarrassed" about her association with the US (lines 3, 9-10). Notably, the use of turn-final "honestly" here "attend[s] to correcting the question asker's assumptions or presuppositions about what the answerer should know" (Edwards and Fasulo 2006: 369), in this case, problematizing the presumed assumption on Lara's part that the conversation would have gone well.

Following an account for why she felt surprised that Fen didn't want to visit the US in light of her connection (i.e., having been born there) (data not shown), Jill recognizably trails off her talk at the point excerpt (4) begins.

(4) AmAus26_follow-up(J): 1:33

$75 \mathrm{~J}:$ so I don't kno:w [but ] um

76 L:

[wo:w]

$77 \quad(0.2)$

78 L: were you offended by anything (.)[that she] said?

$79 \mathrm{~J}$ :

[um hhh]

$80 \quad(2.6)$

$81 \mathrm{~J}:$ a little bit (.) bu:t I try not to be?=

82 L: [mm:

83 J: [but it's (so) it's

84 (1.5)

85 L: any £specifics? [like what (.)

In line 75, Jill leaves something hearably unsaid through the utterance-final, trailing off "but" (Walker 2012), thereby orienting to a possible delicacy (Lerner 2013; Haugh 2015), namely, the impropriety of Fen's embarrassment about being associated with the US and her reluctance to go and visit. Lara then offers a candidate understanding in lines 78 of what Jennifer has left unsaid, namely, that she was "offended". Given the format of this inquiry as a polar question that positions being offended as the candidate answer (Pomerantz 1988), Lara thereby indicates her inference about what Jill has left unsaid.

After a noticeably long gap (2.6 seconds, line 80 ), Jill reformulates in line 81 what she has up until to this point left unsaid as "a little bit [offended]", thereby mildly resisting the terms of Lara's question (Heritage and Raymond 2012). However, this resistance is subsequently accounted for when Jill makes a try-claim, namely, that she tried not to be offended (line 81). She thereby explicitly orients to the matter of taking offence as one of personal agency. While Jill launches a continuation of this turn in line 83 with what appears to be something designed to be in contrast with this attempt to not be offended 
due to its contrastive prefacing ("but" in line 83), this is then abandoned. After a noticeable gap (line 84), Lara launches an inquiry about the specifics of what happened (line 85). It is thus left unsaid what Jill may have been about to articulate with respect to her attempt to try and not be offended. In sum, then, through this try-claim, Jill not only explicitly invokes an agentive choice to not display offence at Fen's other-criticism, she also scalar implicates (Haugh 2015: 205) that she was nevertheless to some degree offended (albeit "not deeply offended" as subsequently went on to claim - data not shown).

One account that Jill offers for not taking offence, or at least trying not to show it in her prior interaction with Fen, is Jill's construction of such othercriticism as something she has come to expect.

(5) AmAus26_follow-up(J): 2:15

$103 \mathrm{~J}$ : I- I don’t know (.) um

$104 \quad(1.3)$

$105 \mathrm{~J}$ : (it's) I- I kind of I guess I was kind of (.)

106 kind of a- (.) er similar stuff I was- was

107 expecting [bu

$108 \mathrm{~L}: \quad[\mathrm{m}: \mathrm{m}$

$109 \quad(0.8)$

$110 \mathrm{~J}:$ or I- (.) or I've heard before (.)

$111 \mathrm{~L}: \mathrm{mM}$ :

$112 \mathrm{~J}$ : but (.) .hh I think also just (0.3) just (.) kind

113 of how: (0.8) n- negative her and some other

114 people's attitudes are (.) about the US and >you

115 know<

In the above excerpt, Jill construes the negative attitude of Fen and others about the US and Americans (lines 112-115) as something she was "expecting" (lines 105-107) and that she's "heard before" (line 110). In this way, Jill works to normalize such other-criticisms at the same time as depersonalizing them.

While other-criticisms are evidently dispreferred actions in initial interactions, the above case was not by any means the only instance we found in our dataset. In the following interaction, between Greg and Joanne, two Australian undergraduate students, Joanne laughs and expresses emphatic surprise when Greg says that his field of study is political science. ${ }^{10}$ In laughing in response

10 At the time of recording there was significant controversy about the leadership of the Australian Labor party (in particular, the ongoing white-anting of Julia Gillard's leadership by the former leader Kevin Rudd), something which Greg himself alludes to in the follow-up interview (data not shown). 
to hearing what Greg studies, Joanne takes a disaffiliative stance towards Greg's area of study, and thus by inference, Greg himself.

(6) 8-2-12 JG: 1:30

$25 \mathrm{~J}:$ what- what d'ya study?

$26(0.4)$

27 G: um:. (.) political sci:ences (.) basically.

$28 \quad(0.5)$

$29 \mathrm{~J}: \quad \mathrm{o}(\mathrm{h}) \mathrm{h}$ m(h)y h- h- g(H)odHHHhhe $\uparrow . \mathrm{hh}[\mathrm{hh}$ ]

$30 \mathrm{G}$ :

[yea:h.]

$31 \mathrm{J:} \quad[. \mathrm{HHhh}] \mathrm{oh}: \mathrm{:}:$.

$32 \mathrm{G}:\left[{ }^{\circ} \cdot \mathrm{hh}^{\circ}\right]$

33 (0.8)

34 G: nah: if I probably had my time again I

35 might've (0.5) I don't know studied like

36 aviation or something like that.=[you know $\left.\_\right]$

$37 \mathrm{~J}: \quad$ [fyea:h.£ ]

38 G: [been] a pi:lot, [hh

$39 \mathrm{~J}:$ [wh- ] [wh- what does politica::1,

40 s- is political sci个ence?

Excerpt (6) begins with a presentation-eliciting question (Svennevig 1999), specifically, a "category-activity question" that involves activities related to the categorization of a person (Sacks 1972). Greg's short response (Gardner 2001), which simply states what he studies (line 27), proffers an opportunity for Joanne to "display interest" in the topic of what Greg studies through either a continuer or a self-directed comment, while the turn-final "basically" alludes to the situation being more complex than what is outlined in his response, and thus potentially requiring further elaboration.

Joanne's subsequent turn in line 29 thus constitutes an accountably noticeable absence with respect to such a topicalizer (Maynard and Zimmerman 1984: 311). She responds with a "oh my god", response cry that is delivered with an intonation designed to appear as-if-visceral (Wilkinson and Kitzinger 2006: 161), although also indicating "surprise" in a sequential environment where the prior is evidently not designed as a "surprise source" (Wilkinson and Kitzinger 2006: 158). This reveals a "discrepancy ... between the interactants' taken-forgranted understandings of, or orientations to, some feature of their world" (Wilkinson and Kitzinger 2006: 173-174), in this case the nature of political science as a field of study. The degree of surprise claimed by Joanne is increased through the interpolation of laughter particles in the surprise token, 
which construe this as hearably "laughing at" (Jefferson 1972: 300-301; Glenn 1995), either the idea of studying politics itself or the notion of politics as an area for scientific study, and thus inferably a case of "laughing at" Greg himself (Sacks 1972). However, while the high-pitched in-breath morphing into breathy "oh" in line 31, indexes this as new information (Heritage 1984b), the interpolated aspiration particles orient to the expression of surprise as also somehow problematic (Potter and Hepburn 2010). In this case, then, the "oh my god" response itself is oriented to as a new interactional trouble source by Joanne.

This emphatic claim of surprise and "laughing at" delivery implicates a critical stance towards Greg's chosen field of study. However, this laughter is not subsequently shared by Greg and so the laughable referent (either Greg himself or the subject 'political science') is also not shared by both participants. The fact that this surprise is evidently not shared works to "partition [the] cointeractants into different (sub)cultural memberships" (Wilkinson and Kitzinger 2006: 174). The disaffiliative nature of this "laughing at" response, which "promotes distancing, disparagement, feelings of superiority" (Glenn 2003: 112), is further exacerbated in light of the finding that the preferred response to selfdisclosures in initial interactions amongst (Australian as well as American) speakers of English are positive assessments (Haugh and Carbaugh 2015).

The disaffiliative character of Joanne's response is oriented to by Greg in his subsequent response in line 34, with the turn-initial 'no'-prefacing working to deny the prior disaffiliative off-record assessment implicated through Joanne's prior turn (Raclaw 2013). In other words, Greg's 'no'-prefaced response both indexes, as well as denies the disaffiliative stance implemented by Joanne in her previous turn (Raclaw 2013: 27). At the same time, however, it is designed to precede a "claim to agreement" (Raclaw 2013: 36) as a means for "managing prior disaffiliation" (Raclaw 2013: 34), and indeed, this is what follows in the form of an "unprompted self-disclosure" (Haugh and Carbaugh 2015), through which Greg makes a claim to a "baulked desire" to have studied something else (lines 34-36, 38). This claim distances Greg from the laughable in question (the subject of study). In this way, Greg affiliates with Joanne's affective stance that politics is not a good thing to be studying, thus agreeing both with the implicated criticism, as well as conceding the implicated challenge to his chosen field of study. ${ }^{11}$

This unprompted self-disclosure is not dealt with as problematic, as Joanne aligns with Greg's move to treat political science (and so perhaps not Greg

11 Greg subsequently offers an account for such an implicated challenge, namely, that the job prospects for graduates of political science are not good (data not shown). 
himself) as the subject of the laughter. Notably, however, Joanne responds to Greg's baulked desire to have studied something else with a questioning "yeah" response (line 37) that is delivered with smile voice, which in this case is indicative of suppressed laughter (Jefferson 2004b). In this way, she continues to treat his chosen field of study as a laughable (Holt 2011), thus indicating a disaffiliative stance vis-à-vis his attempt to implement an affiliative stance (Greer et al. 2005).

In this brief excerpt, then, the potential impropriety on Joanne's part is oriented to by Greg through his 'no'-prefacing, as well as through his claimed baulked desire by which he appears to express regret about his chosen field of study. Joanne, however, does not implement a repair despite the way in which both her initial laughing response and Greg's subsequent response are both implemented as dispreferred responses. However, Joanne subsequently attempts to regain composure (Goffman 1956) through a continuer question (lines 39-40), thereby implicitly orienting to the interactional trouble that has just occurred. Notably, Greg construes her response, both implicitly in the interaction itself, and explicitly in the follow-up interview, as we shall see, as a typical one in order to ground his claim to having not taken offence.

In the following excerpt from an interview with Greg after the interaction, it becomes evident that the way in which Joanne's response was not treated as offensive by Greg was grounded in him exercising his agency in choosing how to respond. Given the apparent interactional delicacy and possible impropriety that emerged in this relatively early point in their interaction, the way in which Greg construes both her response and his response to that proves somewhat instructive. Similar to the way in which Jennifer dealt with the other-criticism of Americans, Greg normalizes her emphatic surprise and implicated othercriticism and other-challenge (i.e., questioning his chosen field of study) as a typical reaction that he often gets from others upon hearing he studies politics.

(7) 8-2-12 JG_follow-up(G): 11:56.00

$205 \mathrm{~N}$ : > what did you think a<bout he:r when she did that.

$206(0.5)$

207 G: .hh 个um (0.6) 个个oh: I (.) I don't really care?

208 oh: >you know< I sometimes I get um:. hh (.) .hh

209 you know I get (0.9) > 个well.< (0.4) you know

210 like exci:ted [you ] know like I like you know=

$211 \mathrm{~N}$ : [mhm]

$212 \mathrm{G}$ : =when people go oh $\uparrow$ wow like oh politics or w-

213 wow like well: (0.3) .hh maybe it- it's a chance

214 to you know stick up for the good ol- liberal 
215 a:rts like you know [say ] it's interesting= $216 \mathrm{~N}$ : $\quad\left[{ }^{\circ}\right.$ haha $\left.{ }^{\circ}\right]$

$217 \mathrm{G}$ : =and all that sorta thing so it's it's .hh (.)

$218 \uparrow \underline{\text { oh }} \uparrow I$ didn’t $\downarrow$ I didn’t you know get upse:t

219 or anything or offended like (.) you know

220 it's it's sh- um: (.) what she did is (0.4) what

221 a lot of people do like [ $\uparrow$ oh] (.) poli- you know=

$222 \mathrm{~N}$ : $\quad[\mathrm{mm}]$

223 G: =like (.) politics l- okay (.) .hh so expla:in

224 that to me or: (.) you know like what she asked

225 so whe:re's that gonna do: (0.5) take you in

226 terms of job prospects an all that so: (.) .hh

$227 \uparrow$ 个eah no her reaction was just completely normal

228 'n (0.5) fine? like it was

$229 \quad$ (.)

$230 \mathrm{~N}$ : oh.

The excerpt begins with Greg claiming that he didn't "really care" (line 207) in response to interviewer's question about what Greg thought of Joanne at that point (line 205). The way in which Greg's response to the first author's inquiry is 'oh'-prefaced hints at the "question's inappropriateness" (Heritage 1998: 312), here the presumption that Greg might have taken offence. However, Greg then goes on to admit that in some cases he does react more defensively with respect to political science as a field of study (lines 208-210, 212-215, 217), thereby indicating that his response to Joanne could have been otherwise, and so represented an exercising of his agency vis-à-vis the taking of offence.

Greg then recasts in lines 218-219 his prior response to the interviewer's prior inquiry to not getting "upset" or "offended", thus explicitly rejecting the presumption he might have been offended. He then normalizes Joanne's response as something others have done to him (lines 223-226), namely, a questioning challenge (Robinson and Bolden 2010; Koshik 2005) that is seeking an account as to where studying politics leads job-wise. Her response is accounted for through a reported non-narrative quotation that is used to "warrant some accountable action" (Couper-Kuhlen 2007: 110), namely, her laughing expression of surprise. Greg then explicitly construes Joanne's response as "completely normal" and "fine" (lines 227-228), although in being prefaced with "yeahno', Greg orients to there being more than one line of interpretation at play here at this point in the interaction (Burridge and Florey 2002; Culpeper and Haugh 2014: 254), namely, that others, including perhaps the interviewer, might view Joanne's response as not necessarily "normal" or "fine." 
In this section, we have examined two instances where implicated othercriticisms arose in initial interactions, an activity type where there is a preference for self-criticism (e.g., self-deprecation) over other-criticism. Close analysis of the sequential environments in which these implicated other-criticisms arose also indicated that these were indeed oriented to by the participants as sources of interactional trouble. However, in both cases the recipients elected to construe the other-criticisms as particular kinds of criticism, namely, ones that were depersonalized with respect to themselves as potential targets, and normalized across speakers. Nevertheless, the way in which the recipients admitted to such moves indicated their understanding that these implicated criticisms could have been treated as improprieties which would licence the taking of offence. In this way, the addressed recipients exercised agency both in the way in which they held the other speaker accountable for a particular kind of other-criticism, and in the way in which they elected to either try to reduce the extent to which they took offence or claimed to not take offence at all. This move to avoid being seen as taking offence in both the interactions themselves and the follow-up interviews is, as we noted previously, consistent with the preference for comity and not taking oneself too seriously in initial interactions amongst mainstream speakers of English in Australian and the U.S. (Schneider 1988; Haugh forthcoming), thereby indicating that the exercising of agency in this way by those participants was nevertheless socially-mediated.

One point that has been alluded to in passing in the course of this analysis is that the construal of these social actions by the recipients proved critical to the extent to which the taking of offence was treated as licensed by these othercriticisms. The construal of social action is, as we have previously noted, an inherently moral activity. In analyzing the interactional achievement of these other-criticisms and other-challenges, it has become evident that they involve an orientation to three key facets of the moral order (Haugh 2015).

In the first instance, they encompass an orientation to the emotional order (Sorjonen and Peräkylä 2012), in particular, their affective status, i.e., "socially shared expectations regarding experiencing, expressing, and sharing of emotions" (Stevanovic and Peräkylä 2014: 192) and their affective stance, i.e., "the valence and the relative strength of emotional expression directed to a copresent or absent target" (Stevanovic and Peräkylä 2014: 193). In the case of implicated other-criticisms, the speakers in question were claiming the right to express negative affect towards someone or something with which the addressed recipient identifies. Since implementing such an affective stance is inconsistent with the affective status presumed in initial interactions, where there is a preference for responding to self-disclosures with positive assessments (Haugh and Carbaugh 2015), the addressed recipients in question reduced th3 
potential degree of inconsistency the between affective stance claimed by the other participant and their presumed affective status through depersonalizing the other-criticism, that is, construing it as a criticism that was not being directed at them in particular. In this way, they also avoided an affective stance (i.e., taking offence) that would licence a negative social evaluation by the other participant that they take themselves too seriously (Haugh forthcoming).

These other-criticisms also encompass an orientation to the deontic order (Stevanovic and Peräkylä 2012, 2014), in particular, their perceived deontic status and stance pertaining to "rights and obligations in requesting for, deciding about, and performing actions in the world" (Stevanovic and Peräkylä 2014: 190). In the case of implicated other-criticism, the speakers in question were claiming the right to pass judgement on someone or something with which the addressed recipient identifies. Implementing such a deontic stance is inconsistent with the presumed deontic status of participants in initial interactions in light of the preference for self-criticism (i.e., self-deprecation) over other-criticism (Pillet-Shore forthcoming). In our analysis, the addressed recipients in question reduced the potential degree of inconsistency between the deontic stance claimed by the other participant and their presumed deontic status by normalizing the other-criticism, and treating it as a judgement or belief that is commonly held by many people (at least in their experience).

\section{Implications}

In this paper we have suggested that the agency of recipients ought to be taken into account in theorizing about evaluations of impoliteness. We undertook a close interactional analysis of instances where potentially impolite actions, namely implicated other-criticisms in initial interactions, were not treated as offensive, despite the fact that all of the participants evidently recognized their delicacy and potential impropriety. In construing those other-criticisms in particular ways and electing not to take offence, the recipients in both cases exercised their agency in not holding the other speakers accountable for causing offence. Notably, in both cases, they justified in part their decision to not take offence, or at least to try not to take offence, despite such offence being licensed by the actions of the other participant in question, by depersonalizing and normalizing these other-criticisms.

Our tentative conclusion is that participants inevitably exercise agency in displaying offence because registering offence is itself an accountable social action (Haugh 2015). In theorizing impoliteness, then, we need to take into 
account not only recipients' perceptions of social norms, and in some cases the perceived intentions of the speaker in question, but also the socially-mediated agency of those recipients. In this way, we propose a move beyond the ongoing norms versus intention debate in impoliteness research, towards a deeper consideration of the role of the presumed agency of interactants that underpins, in part, the inevitable accountability of all social action, and the socially-mediated agency exercised by recipients in holding others accountable (or not) for causing offence. In short, we have proposed that producers can be held accountable for impolite stances because they are presumed to exercise agency in implementing social actions, while recipients can exercise agency in choosing to hold or not hold producers accountable for impolite or offensive stances, as well as exercising agency in the ways in which they construe the social actions in question that potentially license the taking of offence on their part. Alongside so-called norms and (perceived) speaker intentions, then, we should also be paying greater attention to issues of socially-mediated agency in our theorization of impoliteness.

It is now well attested to that evaluations of impoliteness may vary across speakers (Eelen 2001; Haugh 2010a; Chang and Haugh 2011; Mills 2011). This variability can be traced back in part to the way in which different participants may perceive the intentions of speakers, or the way in which social norms or expectations presumed by some participants may not align with those presumed by others. However, the agency exercised by recipients (and indeed speakers) offers an additional theoretically motivated source for the inevitable variability in the evaluations of impoliteness across participants. Indeed, we would suggest that agency may yet prove to be a key variable in accounting for variability in evaluations of (im)politeness across populations of speakers.

Acknowledgements: We would like to thank Lara Weinglass for her assistance in making the recordings of the initial interactions, and also in conducting follow-up interviews. We would like to thank Rod Gardner for the analytical insights he shared on the data, as well as Alessandro Duranti for reviewing an earlier draft of this paper; your insights were extremely helpful in informing our discussions. Finally, the second author would also like to acknowledge the support of a Discovery grant from the Australian Research Council (DP120100516) that has enabled part of the dataset examined in this paper to be collected. 


\section{References}

Ahearn, Laura. 2001. Language and agency. Annual Review of Anthropology 30. 109-137.

Archer, Dawn. 2008. Verbal aggression and impoliteness: Related or synonymous? In Derek Bousfield \& Miriam Locher (eds.), Impoliteness in language: Studies on its interplay with power in theory and practice, 181-210. Berlin: Mouton de Gruyter.

Arundale, Robert. 2006. Face as relational and interactional: A communication framework for research on face, facework, and politeness. Journal of Politeness Research 2(2). 193-216.

Arundale, Robert. 2010. Constituting face in conversation: Face, facework and interactional achievement. Journal of Pragmatics 42(8). 2078-2105.

Arundale, Robert. Forthcoming. Doing relating: Constituting face in everyday talk. Oxford: Oxford University Press.

Beach, Wayne. 1993. Transitional regularities for 'casual' "okay" usages. Journal of Pragmatics 19(4). 325-352.

Blitvich, Pilar Garcés-Conejos. 2009. Impoliteness and identity in the American news media: The "Culture Wars". Journal of Politeness Research 5(2). 273-303.

Bousfield, Derek. 2007. Beginnings, middles and ends: A biopsy of the dynamics of impolite exchanges. Journal of Pragmatics 39(12). 2185-2216.

Bousfield, Derek. 2008. Impoliteness in interaction. Amsterdam: John Benjamins.

Bousfield, Derek. 2010. Researching impoliteness and rudeness: Issues and definitions. In Miriam Locher \& Sage Graham (eds.), Interpersonal pragmatics, 101-134. Berlin: Mouton de Gruyter.

Bousfield, Derek \& Miriam Locher. (eds.) (2008). Impoliteness in language. Berlin: Mouton de Gruyter.

Brown, Penelope \& Stephen Levinson. 1987. Politeness. Some universals in language usage. Cambridge: Cambridge University Press.

Burridge, Kate \& Margaret Florey. 2002. 'Yeah-no he's a good kid': A discourse analysis of yeah-no in Australian English. Australian Journal of Linguistics 22(2). 149-171.

Chang, Wei-Lin Melody \& Michael Haugh. 2011. Evaluations of im/politeness of an intercultural apology. Intercultural Pragmatics 8(3). 411-442.

Clayman, Steven \& John Heritage. 2014. Benefactors and beneficiaries: Benefactive status and stance in the management of offers and requests. In Paul Drew \& Elizabeth Couper-Kuhlen (eds.), Requesting in social interaction, 51-82. Amsterdam: John Benjamins.

Couper-Kuhlen, Elizabeth. 2007. Assessing and accounting. In Elizabeth Holt \& Rebecca Clift (eds.), Reporting talk. Reported speech in interaction, 81-119. Cambridge: Cambridge University Press.

Culpeper, Jonathan. 1996. Towards an anatomy of impoliteness. Journal of Pragmatics 25(3). 349-367.

Culpeper, Jonathan. 2005. Impoliteness and entertainment in the television quiz show: The Weakest Link. Journal of Politeness Research 1(1). 35-72.

Culpeper, Jonathan. 2008. Reflections on impoliteness, relational work and power. In Derek Bousfield \& Miriam Locher (eds.), Impoliteness in language: Studies on its interplay with power in theory and practice, 17-44. Berlin: Mouton de Gruyter.

Culpeper, Jonathan. 2011a. Impoliteness: Using language to cause offence. Cambridge: Cambridge University Press. 
Culpeper, Jonathan. 2011b. Politeness and impoliteness. In Karin Aijmer \& Gisle Anderson (eds.), Pragmatics of Society, 393-438. Berlin: Mouton de Gruyter.

Culpeper, Jonathan. 2015. Impoliteness strategies. In Alessandro Capone \& Jacob Mey (eds.) Interdisciplinary studies in pragmatics, culture and society, 421-445. New York: Springer.

Culpeper, Jonathan, Derek Bousfield \& Anne Wichmann. 2003. Impoliteness revisited: With special reference to dynamic and prosodic aspects. Journal of Pragmatics 35(10/11). 1545-1579.

Culpeper, Jonathan \& Michael Haugh. 2014. Pragmatics and the English language. Basingstoke: Palgrave Macmillan.

Dobs, Abby \& Pilar Garcés-Conejos Blitvich. 2013. Impoliteness in polylogal interaction: Accounting for face-threat witnesses' responses. Journal of Pragmatics 53. 112-130.

Drew, Paul. 2011. Reflections on the micro-politics of social action, in interaction. Paper presented at the $12^{\text {th }}$ International Pragmatics Association Conference, University of Manchester, UK, 3-8 July.

Drew, Paul. 2013. Turn design. In Jack Sidnell \& Tanya Stivers (eds.), Handbook of conversation analysis, 131-149. Malden, MA: Wiley-Blackwell.

Du Bois, John. 2007. The stance triangle. In Robert Englebretson (ed.), Stancetaking in discourse. subjectivity, evaluation, interaction, 139-182. Amsterdam: John Benjamins.

Du Bois, John \& Elise Kärkkäinen. 2012. Taking a stance on emotion: Affect, sequence, and intersubjectivity in dialogic interaction. Text \& Talk 32(4). 433-451.

Duranti, Alessandro. 2004. Agency in language. In Alessandro Duranti (ed.), A companion to linguistic anthropology, 451-473. Malden, MA: Blackwell.

Dynel, Marta. 2013. On impoliteness and drama discourse: An interview with Jonathan Culpeper. International Review of Pragmatics 5(1). 163-188.

Edwards, Derek \& Alessandra Fasulo. 2006. 'To be honest': Sequential uses of honesty phrases in talk-in-interaction. Research on Language in Social Interaction 39(4). 343376.

Eelen, Gino. 2001. A critique of politeness theories. Manchester: St. Jerome Publishing.

Gagné, Nana Okura. 2010. Reexamining the notion of negative face in the Japanese socio linguistic politeness of request. Language and Communication 30(2). 123-138.

Gardner, Rod. 1997. The conversational object $\mathrm{mm}$ : A weak and variable acknowledging token. Research on Language and Social Interaction 30(1). 131-156.

Gardner, Rod. 2001. When listeners talk. Amsterdam: John Benjamins.

Gardner, Rod. 2005. Acknowledging strong ties between utterances in talk: Connections through right as a response token. In Ilana Mushin (ed.), Proceedings of the 2004 Conference of the Australian Linguistic Society, 1-12. Available at http://hdl.handle.net/ 2123/115.

Garfinkel, Harold. 1967. Studies in ethnomethodology. Englewood. Cliffs, NJ: Prentice-Hall. Glenn, Phillip. 1995. Laughing at and laughing with: Negotiation of participant alignments through conversational laughter. In Paul ten Have \& George Psathas (eds.), Situated order: Studies in the social organisation of talk and embodied activities, 43-56. Washington, DC: University Press of America.

Glenn, Phillip. 2003. Laughter in interaction. Cambridge: Cambridge University Press. Goffman, Erving. 1956. Embarrassment and social organization. American Journal of Sociology 62(3). 264-271.

Goffman, Erving. 1967. Interaction ritual. New York: Pantheon. 
Grainger, Karen. 2011. 'First order' and 'second order' politeness: Institutional and intercultural contexts. In Linguistic Politeness Research Group (eds.), Discursive approaches to politeness, 167-188. Berlin: Mouton de Gruyter.

Grainger, Karen. 2013. Of babies and bath water: Is there any place for Austin and Grice in interpersonal pragmatics? Journal of Pragmatics 58. 27-38.

Greer, Tim, Yoshiko Usui, Toki Kato, Hitomi Taniguchi \& Vivian Bussinguer Andrade. 2005. Suppressing laughter in the display of (dis)affiliation. Kobe Daigakui Kokusai Komyunikeeshon Sentaa Ronshuu [Kobe University International Communication Centre Bulletin] 2. 27-42.

Haugh, Michael. 2007. The discursive challenge to politeness theory: An interactional alternative. Journal of Politeness Research 3(2). 295-317.

Haugh, Michael. 2008. Intention and diverging interpretings of implicature in the "uncovered meat" sermon. Intercultural Pragmatics 5(2). 201-529.

Haugh, Michael. 2010a. When is an email really offensive?: Argumentivity and variability in evaluations of impoliteness. Journal of Politeness Research 6(1). 7-31.

Haugh, Michael. 2010b. Jocular mockery, (dis)affiliation and face. Journal of Pragmatics 42(8). 2106-2119.

Haugh, Michael. 2010c. Intercultural im/politeness and the micro-macro issue. In Anna Trosborg (ed.), Pragmatics across languages and cultures, 139-66. Berlin: Mouton de Gruyter.

Haugh, Michael. 2011. Practices and defaults in interpreting disjunction. In Kasia Jaszczolt \& Keith Allan (eds.), Salience and defaults in utterance processing, 189-225. Berlin: Mouton de Gruyter.

Haugh, Michael. 2012a. Epilogue: The first-second order distinction in face and politeness research. Journal of Politeness Research 8(1). 111-134.

Haugh, Michael. 2012b. Conversational interaction. In Keith Allan \& Kasia M. Jaszczolt (eds.), The Cambridge handbook of pragmatics, 251-274. Cambridge: Cambridge University Press.

Haugh, Michael. 2013a. Speaker meaning and accountability in interaction. Journal of Pragmatics 48. 41-56.

Haugh, Michael. 2013b. Im/politeness, social practice and the participation order. Journal of Pragmatics 58. 52-57.

Haugh, Michael. 2015. Im/politeness implicatures. Berlin: Mouton de Gruyter.

Haugh, Michael. Forthcoming. Mockery and (non-)seriousness in initial interactions amongst American and Australian speakers of English. In Donal Carbaugh (ed.), Handbook of communication in cross-cultural perspective. London: Routledge.

Haugh, Michael \& Derek Bousfield. 2012. Mock impoliteness, jocular mockery and jocular abuse in Australian and British English. Journal of Pragmatics 44(9). 1099-1114.

Haugh, Michael, Daniel Z. Kádár \& Sara Mills. 2013. Interpersonal pragmatics: Issues and debates. Journal of Pragmatics 58. 1-11.

Haugh, Michael \& Donal Carbaugh. 2015. Self-disclosure in initial interactions amongst speakers of American and Australian English. Multilingua 34(3).

Heritage, John. 1984a. Garfinkel and ethnomethodology. Cambridge: Polity Press.

Heritage, John. 1984b. A change of state token and aspects of its sequential placement.

In J. Maxwell Atkinson \& John Heritage (eds.), Structures of social action, 299-345.

Cambridge: Cambridge University Press.

Heritage, John. 1998. Oh-prefaced responses to inquiry. Language in Society 27(3). 291-334. 
Heritage, John. 2012. Epistemics in action: Action formation and territories of knowledge. Research on Language and Social Interaction 45(1). 1-29.

Heritage, John. 2013. Action formation and its epistemic (and other) backgrounds. Discourse Studies 15(5). 551-578.

Heritage, John \& Geoffrey Raymond. 2012. Navigating epistemic landscapes: Acquiescence, agency and resistance in responses to polar questions. In Jan P. de Ruiter (ed.), Questions: Formal, functional and interactional perspectives, 179-192. Cambridge: Cambridge University Press.

Holt, Elizabeth. 2011. On the nature of 'laughables': Laughter as a response to overdone figurative phrases. Pragmatics 21(3). 393-410.

Holt, Elizabeth. 2012. Using laugh responses to defuse complaints. Research on Language and Social Interaction 45(4). 430-48.

Hutchby, Ian. 2008. Participants' orientations to interruptions, rudeness and other impolite acts in talk-in-interaction. Journal of Politeness Research 4(2). 221-241.

Jefferson, Gail. 1972. Side sequences. In David Sudnow (ed.), Studies in social interaction, 294-338. New York: The Free Press.

Jefferson, Gail. 2004a. Glossary of transcript symbols with an introduction. In Gene Lerner (ed.), Conversation Analysis: Studies from the first generation, 13-23. Amsterdam: John Benjamins.

Jefferson, Gail. 2004b. A note on laughter in 'male-female' interaction. Discourse Studies 6(1). 117-133.

Kádár, Dániel. Z. \& Michael Haugh. 2013. Understanding politeness. Cambridge: Cambridge University Press.

Kádár, Dániel. Z. \& Rosina Marquez-Reiter. 2015. (Im)politeness and (im)morality: Insights from intervention. Journal of Politeness Research 11(2). 239-260.

Kärkkäinen, Elise. 2003. Epistemic stance in English conversation. Amsterdam: John Benjamins.

Koshik, Irene. 2005. Beyond rhetorical questions: Assertive questions in everyday interaction. Amsterdam: John Benjamins.

Lerner, Gene. 2013. On the place of hesitating in delicate formulations: A turn-constructional infrastructure for collaborative indiscretion. In Makoto Hayashi, Geoffrey Raymond \& Jack Sidnell (eds.), Conversational repair and human understanding, 95-134. Cambridge: Cambridge University Press.

Locher, Miriam \& Derek Bousfield. 2008. Introduction: Impoliteness and power in language. In Derek Bousfield \& Miriam Locher (eds.), Impoliteness in language, 1-16. Berlin: Mouton de Gruyter.

Locher, Miriam \& Richard Watts. 2008. Relational work and impoliteness: Negotiating norms of linguistic behaviour. In Derek Bousfield \& Miriam Locher (eds.), Impoliteness in language, 1-16. Berlin: Mouton de Gruyter.

Maynard, Douglas \& Don Zimmermann. 1984. Topical talk, ritual and the social organization of relationships. Social Psychology Quarterly 47(4). 301-316.

McElhinny, Bonnie. 1998. Genealogies of gender theory: Practice theory and feminism in sociocultural and linguistic anthropology. Sociology Annual 42(3). 164-189.

Mills, Sara. 2003. Gender and politeness. Cambridge: Cambridge University Press.

Mills, Sara. 2005. Gender and impoliteness. Journal of Politeness Research 1(2). 263-280.

Mills, Sara. 2011. Discursive approaches to politeness and impoliteness. In Linguistic Politeness Research Group (eds.), Discursive approaches to politeness, 19-56. Berlin: Mouton de Gruyter. 
Mitchell, Nathaniel. forthcoming. Agency and evaluations of impoliteness. Brisbane: Griffith University unpublished PhD dissertation.

Pillet-Shore, Danielle. 2015. Being a "good parent" in parent-teacher conferences. Journal of Communication 65(2). 373-395.

Pomerantz, Anita. 1988. Offering a candidate answer: An information seeking strategy. Communication Monographs 55(4). 360-373.

Pomerantz, Anita. 2005. Using participants' video-stimulated comments to complement analyses of interactional practices. In Hedwig te Molder \& Jonathan Potter (eds.), Conversation and cognition, 93-113. Cambridge: Cambridge University Press.

Pomerantz, Anita. 2012. Do participants' reports enhance conversation analytic claims? Explanations of one sort or another. Discourse Studies 14(4). 499-505.

Pomerantz, Anita \& John Heritage. 2013. Preference. In Jack Sidnell \& Tanya Stivers (eds.), Handbook of conversation analysis, 210-228. Malden, MA: Wiley-Blackwell.

Potter, Jonathan. 1998. Discursive social psychology: From attitudes to evaluative practices. European Review of Social Psychology 9(1). 233-266.

Potter, Jonathan \& Alexa Hepburn. 2005. Qualitative interviews in psychology: Problems and possibilities. Qualitative Research in Psychology 2(4). 281-307.

Potter, Jonathan \& Alexa Hepburn. 2010. Putting aspiration into words: 'Laugh particles', managing descriptive trouble and modulating action. Journal of Pragmatics 42(6). 1543-1555.

Raclaw, Joshua. 2013. Indexing inferables and organisational shifts: 'No'-prefaces in English Conversation. Colorado: University of Colorado unpublished PhD dissertation.

Robinson, Jeffrey. 2013. Overall structural organization. In Jack Sidnell \& Tanya Stivers (eds.), Handbook of conversation analysis, 257-280. Malden, MA: Wiley-Blackwell.

Robinson, Jeffrey \& Galina Bolden. 2010. Preference organization of sequence-initiating actions: The case of explicit account solicitations. Discourse Studies 12(4). 501-533.

Sacks, Harvey. 1972. An initial investigation of the usability of conversational data for doing sociology. In David Sudnow (ed.), Studies in social interaction, 31-75. New York: The Free Press.

Sacks, Harvey, Emanuel Schegloff \& Gail Jefferson. 1974. A simplest systematics for the organisation of turn-taking for conversation. Language 50(4). 696-735.

Schegloff, Emanuel. 2007. Sequence organization in interaction. Cambridge: Cambridge University Press.

Schneider, Klaus P. 1988. Small talk: Analysing phatic discourse. Marburg: Hitzeroth.

Schiffrin, Deborah. 1987. Discourse markers. Cambridge: Cambridge University Press.

Sert, Olcay \& Christine Jacknick. 2015. Student smiles and the negotiation of epistemics in L2 classrooms. Journal of Pragmatics 77. 97-112.

Shaw, Chloë, Alexa Hepburn \& Jonathan Potter. 2013. Having the last laugh: On postcompletion laughter particles. In Phillip Glenn \& Elizabeth Holt (eds.), Studies of laughter in interaction, 91-106. London: Bloomsbury.

Sifianou, Maria. 2012. Disagreements, face and politeness. Journal of Pragmatics 44(12). 1554-1564.

Sorjonen, Marja-Leena \& Anssi Peräkylä. 2012. Introduction. In Anssi Peräkylä \& MarjaLeena Sorjonen (eds.), Emotion in interaction, 3-15. Oxford: Oxford University Press.

Spencer-Oatey, Helen. 2007. Theories of identity and the analysis of face. Journal of Pragmatics 39(4). 639-656.

Sperber, Dan \& Deirdre Wilson. 1995. Relevance. Communication and cognition, $2^{\text {nd }}$ edn. Malden, MA: Blackwell. 
Stevanovic, Melisa \& Anssi Peräkylä. 2012. Deontic authority in interaction: The right to announce, propose, and decide. Research on Language and Social Interaction 45(3). 297-321.

Stevanovic, Melisa \& Anssi Peräkylä. 2014. Three orders in the organization of human action: On the interface between knowledge, power, and emotion in interaction and social relations. Language in Society 43(2). 185-207.

Stivers, Tanya. 2010. An overview of the question-response system in American English conversation. Journal of Pragmatics 42(10). 2772-2781.

Stivers, Tanya. 2013. Sequence organisation. In Jack Sidnell \& Tanya Stivers (eds.), Handbook of conversation analysis, 191-209. Malden, MA: Wiley-Blackwell.

Stivers, Tanya \& Jeffrey Robinson. 2006. A preference for progressivity in interaction. Language in Society 35(3). 367-392.

Svennevig, Jan. 1999. Getting acquainted in conversation. Amsterdam: John Benjamins.

Terkourafi, Marina. 2005. Beyond the micro-level in politeness research. Journal of Politeness Research 1(2). 237-262.

Terkourafi, Marina. 2008. Toward a unified theory of politeness, impoliteness and rudeness. In Derek Bousfield \& Miriam Locher (eds.), Impoliteness in language, 45-74. Berlin: Mouton de Gruyter.

Terkourafi, Marina. 2011. From Politeness1 to Politeness2: Tracking norms of im/politeness across time and space. Journal of Politeness Research 7(2). 159-185.

Walker, Gareth. 2012. Coordination and interpretation of vocal and visible resources: 'Trailoff' conjunctions. Language and Speech 55(1). 141-163.

Waring, Hansun Zhang, Sarah Creider, Tara Tarpey \& Rebecca Black. 2012. A search for specificity in understanding CA and context. Discourse Studies 14(4). 477-492.

Watts, Richard. 2003. Politeness. Cambridge: Cambridge University Press.

Wilkinson, Sue \& Celia Kitzinger. 2006. Surprise as an interactional achivement: Reaction tokens in conversation. Social Psychology Quarterly 69(2). 150-182.

Zimmermann, Don. 1993. Acknowledgement tokens and speakership incipiency revisited. Research on Language and Social Interaction 26(2). 179-194.

\section{Bionotes}

\section{Nathaniel Mitchell}

Is currently undertaking his PhD under the supervision of Associate Professor Michael Haugh and Dr. Ian Walkinshaw. It focuses on the relationship between agency, accountability and evaluations of impoliteness. Nathaniel is involved in several research projects including the West Australian English socio-phonological project with Professor Gerry Docherty (acoustic phonetics and socio-phonological project) and the Police recruit feedback response project (interactional pragmatics project) with Mr. Alistair Fildes. 


\section{Michael Haugh}

Is an Associate Professor in Linguistics and International English in the School of Languages and Linguistics at Griffith University. His areas of research interest include pragmatics, intercultural communication and conversation analysis. He is co Editor-in-Chief of the Journal of Pragmatics, and the author of a number of papers and books, including $\mathrm{Im} /$ Politeness Implicatures (2015, Mouton de Gruyter), Pragmatics and the English Language (2014, Palgrave Macmillan, with Jonathan Culpeper), and Understanding Politeness (2013, Cambridge University Press, with Dániel Kádár).

Supplemental Material: The online version of this article (DOI: 10.1515/pr-2015-0009) offers supplementary material, available to authorized users. 